\title{
Incorporation of 5-ethynyl-2'-deoxyuridine (EdU) as a novel strategy for identification of the skewed $X$ inactivation pattern in balanced and unbalanced $X$-rearrangements
}

\author{
Luiza Sisdelli $^{1}$ - Angela Cristina Vidi ${ }^{2,3} \cdot$ Mariana Moysés-Oliveira $^{1}$. \\ Adriana Di Battista ${ }^{1}$ - Adriana Bortolai ${ }^{1} \cdot$ Danilo Moretti-Ferreira $^{4}$. \\ Magnus R. Dias da Silva ${ }^{2,3} \cdot$ Maria Isabel Melaragno ${ }^{1} \cdot$ Gianna Carvalheira $^{1}$ (I)
}

Received: 30 September 2015 / Accepted: 28 November 2015 / Published online: 15 December 2015

(C) Springer-Verlag Berlin Heidelberg 2015

\begin{abstract}
X-chromosome inactivation occurs randomly in normal female cells. However, the inactivation can be skewed in patients with alterations in X-chromosome. In balanced $\mathrm{X}$-autosome translocations, normal $\mathrm{X}$ is preferentially inactivated, while in unbalanced $X$ alterations, the aberrant $X$ is usually inactivated. Here, we present a novel strategy to verify the skewed $\mathrm{X}$ inactivation pattern through the incorporation of 5-ethynyl-2'-deoxyuridine (EdU) into cells, in 11 patients: five carriers of balanced X-autosome translocations and six of unbalanced X-chromosome alterations. Since EdU is a labeled nucleoside analog of thymidine, its incorporation during DNA synthesis can reveal late replication regions and the inactive X-chromosome. All EdU findings were validated by the human androgen receptor gene (HUMARA) assay. The late replication regions were easily and quickly visualized in all cells, where inactive Xs are marked with strong green fluorescence. It was
\end{abstract}

L. Sisdelli and A. C. Vidi contributed equally to this work.

Electronic supplementary material The online version of this article (doi:10.1007/s00439-015-1622-x) contains supplementary material, which is available to authorized users.

Gianna Carvalheira

carvalheira@unifesp.br

1 Department of Morphology and Genetics, Universidade Federal de São Paulo, São Paulo 04023-900, Brazil

2 Department of Biochemistry, Universidade Federal de São Paulo, São Paulo, Brazil

3 Department of Medicine, Universidade Federal de São Paulo, São Paulo, Brazil

4 Department of Genetics, Instituto de Biociências de Botucatu, São Paulo State University, São Paulo 18618-970, Brazil observed that the normal X-chromosome was preferentially inactivated in patients with balanced $\mathrm{X}$-autosome translocations; while the aberrant X-chromosome was inactivated in most cells from patients with unbalanced alterations. By performing the fluorescence-based EdU assay, the differences between the active and inactive X-chromosomes are more easily recognizable than by classic cytogenetic methods. Furthermore, EdU incorporation allows the observation of the late replication regions in autosomal segments present in $\mathrm{X}$ derivatives from $\mathrm{X}$-autosome translocations. Therefore, EdU assay permits an accurate and efficient cytogenetic evaluation of the $\mathrm{X}$ inactivation pattern with a low-cost, easy to perform and highly reproducible technique.

\section{Introduction}

$\mathrm{X}$-chromosome inactivation $(\mathrm{XCI})$ is a mechanism of dose compensation in female somatic cells of mammals, which silences most of the genes in one of the two X-chromosomes. The presence of $\mathrm{X}$ inactivation center, mapped at

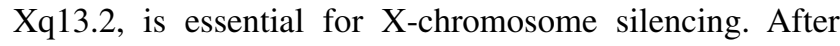
recognizing that a single cell presents two $\mathrm{X}$-chromosomes, $\mathrm{XCI}$ is initiated by transcription of the non-coding XIST gene, located at X inactivation center (Brown et al. 1991; Lee 2009). The non-coding XIST transcript plays as both cis-acting and trans-acting by coating the X-chromatin in both directions from the $\mathrm{X}$ inactivation center. Thus, the epigenetic modifications result in transcriptional gene silencing (Brown et al. 1991, 1992; Engreitz et al. 2013). The inactive $\mathrm{X}$-chromosome can be distinguished by some specific biological properties, such as heterochromatic state (Barr and Bertram 1949), late replication (Willard and Latt 1976), methylation of $\mathrm{CpG}$ islands (Tribioli et al. 1992) and 
histones modifications (Belyaev et al. 1996). All these epigenetic marks serve as chromosomal memory to ensure that this particular $\mathrm{X}$ remains silenced throughout all successive somatic cell cycles. This mechanism is random in normal females, being either the maternal or paternal X-chromosome inactivated in different cells of an individual (Lyon 1961). However, in carriers of X-chromosome alterations, the inactivation is nonrandom (Gartler and Sparkes 1963). In patients with balanced $\mathrm{X}$-autosome translocations, normal X is preferentially inactivated (Mattei et al. 1982). On the other hand, in patients who are carriers of unbalanced $\mathrm{X}$-chromosome alterations (e.g. deletions, duplications or isochromosomes), the aberrant $\mathrm{X}$ is usually inactivated. In fact, the inactivation is a random process followed by a cellular selection favoring the best genetic balance (Gartler and Sparkes 1963).

The XCI pattern can be identified using two main methods. First, by the replicating banding, through incorporation of 5-bromo-2'-deoxyuridine (BrdU) (Latt 1973), and second, by Human Androgen Receptor Assay (HUMARA) (Allen et al. 1992). BrdU is a thymidine analog that can be incorporated during DNA replication, and followed by Hoechst, Giemsa staining and fluorochrome-conjugated with antibodies to detect cell proliferation, replication banding, sister chromatid exchange, and late replicating X-chromosome (Latt 1973; Stults et al. 2014). However, this technique presents little reproducibility. The other molecular methodology used to determine the XCI pattern is the HUMARA, which amplifies only methylated sequences, located at first exon of the $A R$ gene (Xq11.2), after digestion by restriction enzymes sensitive to methylation. The generated X-DNA fragments are linked to the XCI pattern due to the proximity of these cleavage sites to a highly polymorphic short tandem repeat (STR) region, composed by $(\mathrm{CAG})_{n}$ trinucleotides (Allen et al. 1992). Thus, recognizing the inactive $\mathrm{X}$ by HUMARA assay requires the patients to be heterozygous for this polymorphism.

Aiming to analyze cell proliferation, Buck et al. (2008) have recently introduced the incorporation of 5-ethynyl$2^{\prime}$-deoxyuridine (EdU) as an alternative to BrdU assay. Like BrdU, EdU is a thymidine analog with its terminal methyl replaced by an alkyne group (ethynyl). EdU allows its detection by a fluorescent azide (Alexa Fluor ${ }^{\circledR}$ ), which is fast and very specific (Buck et al. 2008). Furthermore, EdU assay has recently been performed in two late replication studies. One of them describes the replication bands in human male metaphases (Hoshi and Ushiki 2011), and the other analyzes asynchronous replication of X-chromosomes in hESC and iPSC lines from a female donor (Bogomazova et al. 2014). Thus, in accordance with these statements and given the fact that the epigenetic modifications in silenced regions present late replication pattern, we propose for the first time a novel strategy to identify the
$\mathrm{X}$-chromosome inactivation pattern through incorporation of EdU in metaphase chromosomes from carriers of balanced and unbalanced $\mathrm{X}$-chromosome alterations.

\section{Subjects and methods}

\section{Patients, cytogenetic analysis, genomic array and array painting}

We have selected 11 patients with alterations on X-chromosome (Table 1). Among them are ten females and one male, the latter being a carrier of a normal X-chromosome and a $\operatorname{dic}(\mathrm{X} ; 15)$, inherited from his mother. Among the females, five are carriers of balanced $\mathrm{X}$-autosome translocations, and five are carriers of unbalanced alterations on X. All patients signed an informed consent document. Their karyotypes and breakpoints were identified by G-banding, array techniques and/or NOR staining. Chromosomal analysis, at 550 resolution G-banding, was performed on lymphocyte cultures using standard methods, and their karyotypes were determined in a total of 20 analyzed metaphases. DNA for genomic array was isolated from peripheral blood using Gentra Puregene Kit (Quiagen-Sciencesm, Germantown, USA). Genomic array was performed using the Affymetrix Genome-Wide Human SNP Array 6.0 (Affymetrix Inc., Santa Clara, CA, USA) or CGH array SurePrint G3 (Agilent Technologies, Palo Alto, CA, USA) and was analyzed, respectively, by the Genotyping Console 3.0.2 and Chromosome Analysis Suite (ChAS) software (Affymetrix), and the CytoGenomics software (Agilent), both according to GRCh37/hg19. Array painting was performed on patients with X-autosome balanced translocations (patients 1 to 5, Table 1), in order to map the rearrangements breakpoints, as described by Moysés-Oliveira et al. (2015a, b).

\section{EdU and FISH assays}

EdU was incorporated in human lymphocyte culture as described by Hoshi and Ushiki (2011) and Bogomazova et al. (2014) with modifications as following. The lymphocytes were isolated from heparinized peripheral blood and cultivated in karyotyping medium PBMAX (Gibco, Life Technologies, Carlsbad, CA, USA) at $37^{\circ} \mathrm{C}$ for $67 \mathrm{~h}$. Next, the cells were treated with $10 \mu \mathrm{M}$ EdU (Invitrogen, Life Technologies, Carlsbad, CA, USA) and incubated for additional $2 \mathrm{~h}$ at $37{ }^{\circ} \mathrm{C}$. The medium was replaced with a recovery fresh medium containing $1 \times$ PBS, and the cell suspension was incubated for an additional $2 \mathrm{~h}$ at $37{ }^{\circ} \mathrm{C}$. The cells were then treated with $0.08 \mu \mathrm{g} / \mathrm{mL}$ colchicine (Sigma Aldrich, Saint Louis, MO, USA) for $45 \mathrm{~min}$, at $37{ }^{\circ} \mathrm{C}$, followed by $75 \mathrm{mM}$ $\mathrm{KCl}$ treatment for $8 \mathrm{~min}$, at $37^{\circ} \mathrm{C}$, and finally fixed in 
Table 1 Patient carriers of X-chromosome alteration karyotypes and HUMARA results

\begin{tabular}{|c|c|c|c|c|c|c|c|}
\hline \multirow[t]{2}{*}{ Patients } & \multirow[t]{2}{*}{ Karyotypes/array } & \multirow{2}{*}{$\begin{array}{l}\text { X-chromosome } \\
\text { alterations }\end{array}$} & \multicolumn{3}{|c|}{ Alleles (bp) } & \multirow{2}{*}{$\begin{array}{l}\text { HUMARA ratios } \\
\text { (digested alleles) }\end{array}$} & \multirow[t]{2}{*}{ XCI pattern } \\
\hline & & & Minor & Intermediate & Major & & \\
\hline $1^{\mathrm{a}, \mathrm{b}}$ & $46, X, t(X ; 3)(q 13.3 ; q 11.2) d n$ & Balanced & 228 & & 234 & $0: 100$ & $\begin{array}{l}\text { Extremely } \\
\text { skewed }\end{array}$ \\
\hline 2 & $46, X, t(X ; 9)(q 23 ; q 12) d n$ & Balanced & 219 & & 231 & 100:0 & $\begin{array}{l}\text { Extremely } \\
\text { skewed }\end{array}$ \\
\hline 3 & $\begin{array}{l}\text { 46,X,dic }(X ; 15) \\
\quad(X q t e r \rightarrow X p 11.1:: 15 p 13 \rightarrow 15 q \text { qter })\end{array}$ & Balanced & 214 & & 235 & $0: 100$ & $\begin{array}{l}\text { Extremely } \\
\text { skewed }\end{array}$ \\
\hline $4^{\mathrm{a}}$ & $46, \mathrm{X}, \mathrm{t}(\mathrm{X} ; 19)(\mathrm{p} 21.1 ; \mathrm{q} 13.4) \mathrm{dn}$ & Balanced & 210 & & 216 & $5: 95$ & $\begin{array}{l}\text { Extremely } \\
\text { skewed }\end{array}$ \\
\hline 5 & 46,X,t(X;21)(p11.22;p11.1) & Balanced & 222 & & 228 & $88: 12$ & Skewed \\
\hline 6 & $46, X, i(X)(q 10)$ & Unbalanced & 228 & & 237 & $97: 3$ & $\begin{array}{l}\text { Extremely } \\
\text { skewed }\end{array}$ \\
\hline 7 & $46, X, \operatorname{del}(\mathrm{X})(\mathrm{p} 21)$ & Unbalanced & 219 & & 260 & 100:0 & $\begin{array}{l}\text { Extremely } \\
\text { skewed }\end{array}$ \\
\hline 8 & 46,X,del $(\mathrm{X})(\mathrm{p} 11.2)$ & Unbalanced & 225 & & 228 & $90: 10$ & Skewed \\
\hline 9 & $\begin{array}{l}\text { 46,XY,dic }(X ; 15) \\
\quad(X q \operatorname{lter} \rightarrow \mathrm{Xp} 11.1:: 15 \mathrm{p} 13 \rightarrow 15 \mathrm{qter}) \text { mat.arr } \\
\quad \mathrm{Xq11.1q28}(61,728,816-155,233,846) \times 2\end{array}$ & Unbalanced & 214 & & 235 & $98: 2$ & $\begin{array}{l}\text { Extremely } \\
\text { skewed }\end{array}$ \\
\hline 10 & 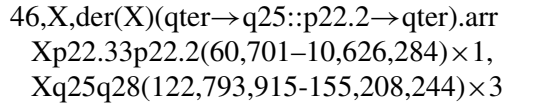 & Unbalanced & 229 & & 241 & 100:0 & $\begin{array}{l}\text { Extremely } \\
\text { skewed }\end{array}$ \\
\hline \multirow[t]{2}{*}{11} & \multirow[t]{2}{*}{$47, \mathrm{XX}, \operatorname{der}(\mathrm{X})(\mathrm{qter} \rightarrow \mathrm{q} 25:: \mathrm{p} 22.2 \rightarrow \mathrm{qter}) \mathrm{mat}$} & \multirow[t]{2}{*}{$\begin{array}{l}\text { Unbalanced (three } \\
\text { X-chromosomes) }\end{array}$} & \multirow[t]{2}{*}{226} & \multirow[t]{2}{*}{229} & 241 & $\begin{array}{l}\text { 66:34 (minor:major) } \\
54: 46 \\
\quad \text { (minor:intermediate) }\end{array}$ & $\begin{array}{l}\text { Indeterminate } \\
\text { Random }\end{array}$ \\
\hline & & & & & & $\begin{array}{l}\text { 62:38 } \\
\quad \text { (intermediate:major) }\end{array}$ & Random \\
\hline
\end{tabular}

a Karyotype described by Moysés-Oliveira et al. (2015a)

b Karyotype described by Moysés-Oliveira et al. (2015b)

Carnoy 3:1 (methanol:acetic acid). Chromosomes spread, treated with EdU, were dropped onto clean glass slides and stored at room temperature overnight. FISH was performed using the $\mathrm{X}$-chromosome centromere probe RU-LPE0XR (Cytocell, Cambridge, UK), according to manufacturer's protocol. EdU incorporation was detected by the click reaction, in which a copper-catalyzed reaction occurs between the alkyne group of EdU and azide group of Alexa Fluor ${ }^{\circledR} 488$ dye (Click-iT EdU Alexa Fluor Cell Proliferation Assay kit, Invitrogen). Two hundred and fifty microliters of the labeling mix with Alexa Fluor $^{\circledR} 488$ dye were dropped onto each slide and incubated for $30 \mathrm{~min}$ in a dark room, at room temperature, according to the manufacturer's protocol (Invitrogen). Finally, the chromosomes were stained with DAPI in Vectashield. The metaphases were analyzed under a fluorescence microscope Zeiss (Carl Zeiss, Jena, Germany) and images were captured using ISIS Karyotype Image System (Metasystems, Altlussheim, Germany). A range of 20-200 cells were analyzed per patient.

\section{Human androgen receptor assay (HUMARA)}

The protocol of HUMARA was performed as previously described by Araújo and Ramos (2008) with modifications. One microgram of DNA, of each patient, was double digested in a $20 \mu \mathrm{L}$ final volume, composed of $20 \mathrm{U}$ HpaII (New England BioLabs, Ipswich, MA, USA) and $20 \mathrm{U}$ HhaI (Promega Corporation, Fitchburg, WI, USA) simultaneously and $1 \times$ Bovine Serum Albumin (New England BioLabs). These reactions were incubated for $16 \mathrm{~h}$ at $37^{\circ} \mathrm{C}$ and enzymes were inactivated at $65^{\circ} \mathrm{C}$ for $10 \mathrm{~min}$. The first PCR reaction was performed in a $25 \mu \mathrm{L}$ final volume with $2 \mu \mathrm{L}$ of digested DNA, $12.5 \mu \mathrm{L}$ of $2 \times$ PCR Master Mix (Promega Corporation) and 10 pmol of each pair primers, described in Table 2. The Nested PCR was performed in a $25 \mu \mathrm{L}$ final volume composed by $2 \mu \mathrm{L}$ of the first PCR product diluted 1000-fold using UltraPure Distilled Water (Invitrogen), $10 \mathrm{pmol}$ of another oligonucleotide primers (Table 2), $0.26 \mathrm{mM}$ dNTPs (Invitrogen), $1 \mathrm{mM} \mathrm{MgCl} 2$ (Invitrogen), 0.1 U Taq DNA Polymerase (Invitrogen) and 
Table 2 Primers used to amplify the first exon of $A R$ gene in HUMARA assay

\begin{tabular}{lllll}
\hline Strand & Sequences & Size & RefSeq AR gene (NCBI) & PCRs \\
\hline Forward 1 & 5'-GGGTAAGGGAAGTAGGTGGAAG-3' $^{\prime}$ 996 bp & NG_009014.2 & First PCR \\
Reverse 1 & 5'-CCTTTGGTGTAACCTCCCTTGA-3' $^{\prime}$ & & & \\
Forward 2 & 5'-FAM-GTGCGCGAAGTGATCCAGAA-3' $^{\prime}$ 244 bp & & Nested PCR \\
Reverse 2 & 5'-CACAGGCTACCTGGTCCTGG-3' $^{\prime}$ & & \\
\hline
\end{tabular}

$1 \times$ enzyme buffer (Invitrogen). The fragment analysis was performed by capillary electrophoresis using apparatus 3130xl Genetic Analyzer (ABI Prism, Applied Biosystems, Life Technologies, Waltham, MA, USA). GeneScan 500 LIZ (Applied Biosystems) was used as molecular weight marker, and samples were 40-fold diluted in UltraPure Distilled Water (Invitrogen). The data from capillary electrophoresis were analyzed using the GeneMapper software (Life Technologies) and the images were obtained using the GeneMarker software (SoftGenetics, Pennsylvania, USA). The PCR reactions were performed in triplicate. Except for patient 11 , which has three X-chromosomes (Table 1), the $\mathrm{PCR}$ reactions were carried out in quintuplicate to obtain a more accurate analysis. The pattern of XCI was determined by the equation proposed by Bolduc et al. (2008) (Supplementary Figure S1). The undigested samples were used both as control of the digested reactions and to calculate the percentage of the digested allele with a major number of $(\mathrm{CAG})_{n}$ repeats. Then, $1 \mu \mathrm{g}$ of genomic DNA was incubated in $1 \times$ enzyme digestion buffer (New England BioLabs), for $16 \mathrm{~h}$ at $37^{\circ} \mathrm{C}$ followed by $95^{\circ} \mathrm{C}$ for $10 \mathrm{~min}$. The undigested samples were subjected to the same PCR conditions described above. Two normal males and one normal female were included in the HUMARA assay, as control of the XCI pattern.

\section{Statistical analysis}

For statistical analysis of the EdU assay, paired Student's $t$ test was used to compare both informative versus noninformative cells and expected versus non-expected $\mathrm{X}$ inactivation. The data were calculated using GraphPad PRISM (Version 5.0, San Diego, CA) and $P$ value $<0.05$ was considered statistically significant.

\section{Results}

\section{Inactive $\mathrm{X}$-chromosome identification by EdU incorporation}

To analyze the replication timing of the inactive $\mathrm{X}$-chromosomes, lymphocyte cultures from patients with $\mathrm{X}$ alterations were exposed to pulse-labeled with EdU before harvesting. To identify the X-chromosome easily, its centromere was marked in red by FISH technique (Fig. 1af). As expected, cells with two or more X-chromosomes showed different times of replication, making it possible to distinguish inactive $\mathrm{X}$ from active ones in most cells analyzed. In these cases, $\mathrm{X}$-chromosome with strong green labeling was identified as an inactive chromosome, while X-chromosome weakly labeled in green was identified as the active one. Cells with this pattern were classified as informative (Fig. 1ai). However, in some cells, both $\mathrm{X}$-chromosomes presented similar labeling intensity, indicating that both $\mathrm{X}$-chromosomes incorporated the same amount of modified uridine, which classified these cells as non-informative (Fig. 1aii).

After EdU incorporation, an average of $76.77 \% \pm 10.5$ of informative cells $(P<0.0001)$ were observed. In five patients with balanced $\mathrm{X}$-autosome translocations, among the informative metaphases, $98.8 \% \pm 1.8$ exhibited inactivation of normal X-chromosome and $1.2 \%$ of the $\operatorname{der}(\mathrm{X})$ (Fig. 1b, $P<0.0001)$. On the other hand, in six patients with unbalanced $\mathrm{X}$ alterations, among the informative cells, $97.4 \% \pm 3.6$ showed inactivation of abnormal X-chromosome and $3.7 \%$ of normal X-chromosome (Fig. 1c-f, $P<0.0001)$.

In the male patient 9 , carrier of the unbalanced translocation with dicentric $(\mathrm{X} ; 15)$ karyotype, EdU incorporation revealed late replication of $\mathrm{Xq}$, from $\operatorname{dic}(\mathrm{X} ; 15)$, in $94 \%$ of informative metaphases. However, the $15 q$ at the same $\operatorname{dic}(\mathrm{X} ; 15)$ chromosome presented variable late replication pattern: in proximal, interstitial and terminal regions (Fig. 1d-e). The late replication of $15 \mathrm{q}$ proximal/interstitial regions was observed in $66.66 \%$ of metaphases (Fig. 1d), while in the $15 \mathrm{q}$ terminal region, the late replication occurred in $86.66 \%$ of analyzed cells (Fig. 1e).

In the female patient 11 , carrier of an extra $\operatorname{der}(\mathrm{X})$, $91 \%$ of informative metaphases showed $\mathrm{X}$ inactivation in one normal X-chromosome and the $\operatorname{der}(\mathrm{X})$ (Fig. 1f). The remaining $9 \%$ of metaphases had only the $\operatorname{der}(\mathrm{X})$ inactive.

\section{HUMARA assay}

To validate the EdU incorporation assay, HUMARA was performed on all 11 carriers of X-chromosome alterations. In all patients analyzed it was possible to identify the XCI pattern (Table 1, Supplementary Figures S2a to S2g), 

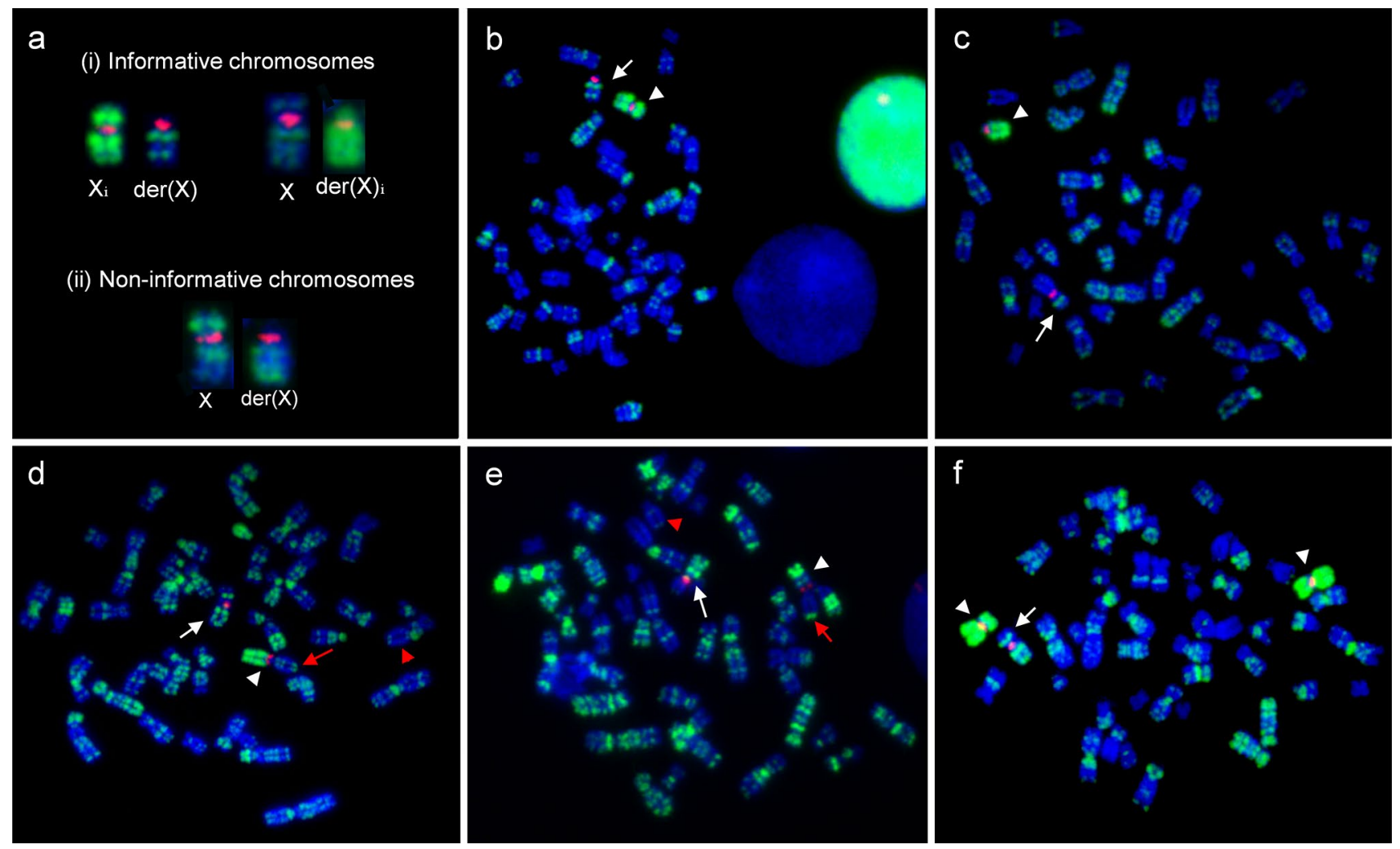

Fig. 1 Results of EdU assay. Chromosomes revealed by Alexa Fluor $^{\circledR} 488$ and counterstained with DAPI; all X-chromosomes were marked with X-centromere probe (red signal). a EdU incorporation pattern in X-chromosomes: (i) two pairs of X-chromosomes marked differently in informative cells, and (ii) a pair of X-chromosomes marked equally in non-informative cells. $\mathbf{b}$ Metaphase from patient 5 , with balanced $\mathrm{t}(\mathrm{X} ; 21)$ translocation, showing the normal X-chromosome inactive (arrow head) and the $\operatorname{der}(\mathrm{X})$ active (arrow). Observe the interphase nuclei in different replication timing revealed by Edu incorporation. c Metaphase from patient 8, with unbalanced $\operatorname{del}(\mathrm{X})$ (p11.2), showing the deleted X inactive (arrow head) and the normal $\mathrm{X}$-chromosome active (arrow). d, e Metaphases from the patient 9,

excluding patient 11 , carrier of an extra $\operatorname{der}(\mathrm{X})$, which was analyzed separately (Supplementary Figure S2h). Among the 10 patients with $\mathrm{X}$ alterations, eight presented extremely skewed XCI pattern (Table 1).

In patient 11, carrier of an extra $\operatorname{der}(\mathrm{X})$, the HUMARA analysis showed three alleles $(226,229$ and $241 \mathrm{bp}$ ), two of them (229 and $241 \mathrm{bp}$ ) inherited from her mother (patient 10), being the $\operatorname{der}(\mathrm{X})$ identified as the carrier of the 241 bp allele (Table 1; Supplementary Figures S2g and $\mathrm{S} 2 \mathrm{~h}$ ). However, this assay was unable to identify the $\mathrm{X}$ inactivation pattern due to the presence of three $\mathrm{X}$-chromosomes. To calculate the XCI pattern, we have combined the area values from the three alleles (minor:major, minor:intermediate and intermediate:major). The minor:major combination suggested intermediate XCI pattern, with $66 \%$ of electropherograms showing the $241 \mathrm{bp}$ allele when these two alleles were compared. In the two with unbalanced $\operatorname{dic}(X ; 15)$, showing inactivation of $X q$ in $\operatorname{dic}(X ; 15)$ chromosomes (white arrow heads), normal $\mathrm{X}$ active (white arrows) and variable late replication into $15 \mathrm{q}$ from the $\operatorname{dic}(\mathrm{X} ; 15)$ (red arrows). The red arrow heads show the normal chromosome 15; d 15q of the $\operatorname{dic}(\mathrm{X} ; 15)$ shows late replication at proximal, interstitial and terminal regions (red arrow), and e $15 \mathrm{q}$ of the $\operatorname{dic}(\mathrm{X} ; 15)$ shows late replication only at terminal region (red arrow). $\mathbf{f}$ Metaphase from patient 11 , with an extra $\mathrm{X}$-chromosome, showing two inactivated $\mathrm{X}$-chromosomes (arrow heads, $\operatorname{der}(\mathrm{X})$ and normal $\mathrm{X}$ ), as well as one active normal X-chromosome (arrow). Xi: inactive X-chromosome; $\operatorname{der}(\mathrm{X})$ : derivative $\mathrm{X}$-chromosome; $\mathrm{X}$ : $\mathrm{X}$-chromosome; $\operatorname{der}(\mathrm{X}) \mathrm{i}$ : inactive derivative $\mathrm{X}$-chromosome (color figure online)

remaining combinations, HUMARA ratios suggested random XCI pattern (Table 1).

\section{Discussion}

We were able to show that the differences between the active and inactive $\mathrm{X}$-chromosomes are more easily demonstrated by performing the fluorescence-based EdU assay than by using classic cytogenetic methods. In fact, EdU assay improved the efficiency of cytogenetic evaluation of the skewed $\mathrm{X}$ inactivation pattern, which can be carried out at low cost as well as with ease and high reproducibility.

It is widely known that epigenetic modifications in the inactive $\mathrm{X}$ interfere in its replication, and the skewed XCI pattern occurs in patients with X rearrangements (Gartler and Sparkes 1963; Mattei et al. 1982; Schluth et al. 2007). 
Although BrdU incorporation can identify the XCI pattern in patients with $\mathrm{X}$ alterations, it is neither a convenient nor a fast technique. To distinguish in situ active and inactive $\mathrm{X}$-chromosomes using $\mathrm{BrdU}$, obtaining good quality metaphases is a laborious, time-consuming process and not highly reproducible. Only after exposing the metaphases slides to ultraviolet light do the late replication regions appear as a differential bleached chromatid by light microscopy. The differential staining of the late replication regions can be subtle and very variable across the metaphases of the same individual, requiring a meticulous optimization of the protocol and an experienced cytogeneticist to analyze the results. The HUMARA assay, as a molecular test to determine the XCI pattern, overcame the need of a high-quality chromosome banding; however, this method has two limitations: (a) it can be applied only in heterozygous carriers to a polymorphic region at $A R$ gene, and (b) it does not discriminate which $\mathrm{X}$-chromosome is the inactivated one (normal or derivative). Thus, we postulate that EdU incorporation could be applied to determine the XCI pattern in patients with $\mathrm{X}$ alterations, discriminating which $\mathrm{X}$-chromosome is preferentially inactivated, in a faster way than the two techniques mentioned above. To achieve this goal, the lymphocyte cultures from patients with $\mathrm{X}$ rearrangements were pulse-labeled with EdU for $2 \mathrm{~h}$, instead of $6.5 \mathrm{~h}$, as described by Hoshi and Ushiki (2011), and $20 \mathrm{~min}$, as described by Bogomazova et al. (2014). In these two previous approaches, the authors had analyzed replication bands in human male metaphases and asynchronous replication of X-chromosomes in hESC and iPSC lines from a female donor, respectively. Bogomazova et al. (2014) used EdU incorporation together with $5 \mathrm{hmC}$-antibody in these cell lines in order to identify the asynchronous replication between the two $\mathrm{X}$-chromosomes, without determining the XCI pattern in these cells. Therefore, by using EdU as a strategy to analyze XCI pattern, we are able to distinguish which $\mathrm{X}$-chromosome is skewed inactive, either normal $\mathrm{X}$ or derivative one, in specific cases of $\mathrm{X}$ alterations. In fact, the late replication in the $\mathrm{X}$-chromosome was identified in a high percentage of the cells ( $76.77 \%$, on average) by the strong green fluorescence from Alexa Fluor $^{\circledR}$ 488. In ten out of 11 patients, HUMARA confirmed the EdU incorporation results, indicating that $80 \%$ presented an extremely skewed $\mathrm{X}$ inactivation and $20 \%$ presented skewed $\mathrm{X}$ inactivation. The exception is patient 11 , carrier of an extra $\operatorname{der}(\mathrm{X})$, in which HUMARA was unable to identify the preferential inactive allele.

In our male patient 9, carrier of the unbalanced translocation with dicentric $(\mathrm{X} ; 15)$ karyotype, HUMARA showed skewed inactivation pattern, and EdU incorporation showed that only the $\mathrm{Xq}$ from the dicentric $(\mathrm{X} ; 15)$ chromosome was preferentially inactive. Further, the EdU incorporation indicated that the $15 \mathrm{q}$ of $\operatorname{dic}(\mathrm{X} ; 15)$ presented variable replication timing. This particular case illustrates how EdU assay can be more informative than the HUMARA method. The late replication region of $15 \mathrm{q}$ proximal in the $\operatorname{dic}(\mathrm{X} ; 15)$ was observed in $66.66 \%$ of the cells, while in $15 q$ terminal region the late replication was observed in $86.66 \%$. Therefore, performing the EdU incorporation, it is possible to visualize the late replication status under autosomal regions in X-autosome rearrangements. These results suggested that although the non-coding XIST transcript can spread the silencing marks, the autosomal inactivation does not appear to occur uniformly or in the same way along the dicentric $(\mathrm{X} ; 15)$ chromosome. This discontinuous and incomplete XIST non-coding RNA (ncRNA) spreading in the $15 \mathrm{q}$ may occur due to the chromatin architecture organization in the interphase nuclei, where the chromosomes can assume the Rabl configuration. In this configuration, chromosomes are aligned with their centromeres towards one pole of the nucleus and their telomeres towards the other (Sumner 2003; Mizuguchi et al. 2015). The incomplete or discontinuous XIST ncRNA spreading has been demonstrated by many cytogenetic and molecular analyses (Keitges and Palmer 1986; Schanz and Steinbach 1989; Scheuerle et al. 1995; Gläser et al. 2004; Panasiuk et al. 2004; Yatsenko et al. 2004; Stankiewicz et al. 2006; Sakazume et al. 2012; Yeung et al. 2014). In fact, the spreading of XIST ncRNA can occur in both cis-acting and trans-acting processes. Thus, the coverage of XIST ncRNA along the $\mathrm{X}$-chromosome depends on the nuclei three-dimensional architecture of the X-chromosome, in which the X-chromatin loops, localized in the same nuclear territory as the XIST transcripts, are more susceptible to its epigenetic modifications (trans-acting) than X-chromosome regions adjacent to XIST locus (cis-acting), but in another nuclear compartment (Engreitz et al. 2013). The Rabl configuration assumed in the interphase nuclei can explain the high percentage of late replication status observed in $15 \mathrm{q}$ terminal from the $\operatorname{dic}(\mathrm{X} ; 15)$ chromosome. Besides the effect of Rabl configuration, the difference in replication timing between $15 q$ proximal and $15 q$ terminal regions may also probably occur due to the dicentric $(X ; 15)$ chromosome constitution. The presence of X-chromosome centromere, nucleolus organization region and chromosome 15 centromere, between $\mathrm{Xq}$ and $15 \mathrm{q}$ sequences, could act as a physical barrier against inactivation spreading under the autosomal region. Resistance to spreading of $\mathrm{X}$ inactivation was also observed in the female patient carrier of unbalanced $\operatorname{dic}(\mathrm{X} ; 15)$, where the additional centromere of 15 presumably acted as a physical barrier as well (Scheuerle et al. 1995).

In patient 11, carrier of an extra $\operatorname{der}(\mathrm{X}), \mathrm{EdU}$ incorporation showed one normal $\mathrm{X}$ active and two inactive $\mathrm{X}$-chromosomes: a normal $\mathrm{X}$-chromosome and $\mathrm{a} \operatorname{der}(\mathrm{X})$ one (this last being inactive in $100 \%$ of the cells). However, the 
HUMARA results were unable to identify the XCI pattern in this patient with three X-chromosomes. In an attempt to calculate the inactivation pattern in patients with three or more X-chromosomes, according to the equation described by Bolduc et al. (2008), three combinations, using the area values from minor, intermediate and major alleles, were measured as follows: minor:major, minor:intermediate and intermediate:major. When minor:major alleles were combined, the HUMARA ratio showed indeterminate XCI pattern, and when minor:intermediate and intermediate:major alleles were combined, the ratio showed random XCI pattern. The failure to estimate the XCI pattern in this case, by the Bolduc et al. (2008) equation, is probably due to the fact that this equation was not fit for patients with three or more $\mathrm{X}$-chromosomes. In this patient, even the $\operatorname{der}(\mathrm{X})$ chromosome being inactivated in all the cells analyzed by EdU assay, the two remaining normal $\mathrm{X}$-chromosomes still present random XCI pattern. Sato et al. (2004) performed HUMARA assay on a patient with three $\mathrm{X}$-chromosomes after bisulfite modification and they were also unable to calculate the XCI pattern. It is important to remember that performing HUMARA assay in both the patient and one of the parents simultaneously has the advantage of enabling the identification of the chromosomal non-disjunction during meiosis phase in patients carrying two or more X-chromosomes. Regarding our patient with an extra derivative $\mathrm{X}$-chromosome, it was possible to infer that the non-disjunction occurred during maternal meiosis I because she inherited two X-chromosomes, one with $229 \mathrm{bp}$ and the other with $241 \mathrm{bp}$ alleles.

To the best of our knowledge, this study is the first to use EdU assay as a novel strategy to discriminate preferential $\mathrm{X}$-chromosome inactivation. This technique is especially important to those who work with gene expression in patients with X-chromosome rearrangements. The study provides evidence that indicates EdU assay to be a sensitive and efficient method to identify which X-chromosome is inactivated in patients with $\mathrm{X}$ alterations, making it possible to visualize both the morphology of inactive $\mathrm{X}$ and the late replication status.

Acknowledgments We thank PhD Dr. Andreas Houben, Leibniz Institute of Plant Genetics and Crop Plant Research (IPK), for his valuable suggestions of the establishment of the EdU assay protocol in our laboratory. This study was funded by the Fundação de Amparo à Pesquisa do Estado de São Paulo (FAPESP).

\section{Compliance with ethical standards}

Conflict of interest None.

\section{References}

Allen RC, Zoghbi HY, Moseley AB, Rosenblatt HM, Belmont JW (1992) Methylation of Hpall and Hhal Sites Near the Polymorphic CAG Repeat in the Human Androgen-Receptor Gene
Correlates with X Chromosome Inactivation. Am J Hum Genet 51:1229-1239

Araújo A, Ramos ES (2008) Cryptic mosaicism involving a second chromosome $\mathrm{X}$ in patients with Turner syndrome. Braz $\mathrm{J}$ Med Biol Res 41:368-372

Barr ML, Bertram EG (1949) A morphological distinction between neurones of the male and female, and the behaviour of the nucleolar satellite during accelerated nucleoprotein synthesis. Nature 163:676-677. doi:10.1038/163676a0

Belyaev ND, Keohane AM, Turner BM (1996) Differential underacetylation of histones $\mathrm{H} 2 \mathrm{~A}, \mathrm{H} 3$ and $\mathrm{H} 4$ on the inactive $\mathrm{X}$ chromosome in human female cells. Hum Genet 97:573-578

Bogomazova AN, Lagarkova MA, Panova AV, Nekrasov ED, Kiselev SL (2014) Reactivation of capital HA, Cyrillic chromosome upon reprogramming leads to changes in the replication pattern and $5 \mathrm{hmC}$ accumulation. Chromosoma 123:117-128. doi:10.1007/s00412-013-0433-x

Bolduc V, Chagnon P, Provost S, Dubé MP, Belisle C, Gingras M, Mollica L, Busque L (2008) No evidence that skewing of X chromosome inactivation patterns is transmitted to offspring in humans. J Clin Invest 118:333-341. doi:10.1172/JCI33166

Brown CJ, Lafreniere RG, Powers VE, Sebastio G, Ballabio A, Pettigrew AL, Ledbetter DH, Levy E, Craig IW, Willard HF (1991) Localization of the $\mathrm{X}$ inactivation centre on the human $\mathrm{X}$ chromosome in Xq13. Nature 349:82-84. doi:10.1038/349082a0

Brown CJ, Hendrich BD, Rupert JL, Lafrenière RG, Xing Y, Lawrence J, Willard HF (1992) The human XIST gene: analysis of a $17 \mathrm{~kb}$ inactive $\mathrm{X}$-specific RNA that contains conserved repeats and is highly localized within the nucleus. Cell 71:527-542

Buck SB, Bradford J, Gee KR, Agnew BJ, Clark ST, Salic A (2008) Detection of S-phase cell cycle progression using 5-ethynyl-2'deoxyuridine incorporation with click chemistry, an alternative to using 5-bromo-2'-deoxyuridine antibodies. Biotechniques 44:927-929. doi:10.2144/000112812

Engreitz JM, Pandya-Jones A, McDonel P, Shishkin A, Sirokman K, Surka C, Kadri S, Xing J, Goren A, Lander ES, Plath K, Guttman M (2013) The Xist lncRNA exploits three-dimensional genome architecture to spread across the X chromosome. Science 341:1237973. doi:10.1126/science. 1237973

Gartler SM, Sparkes RS (1963) The Lyon-Beutler hypothesis and isochromosome $\mathrm{X}$ patients with Turner Syndrome. Lancet 282:411. doi:10.1016/S0140-6736(63)93096-4

Gläser B, Shirneshan K, Bink K, Wirth J, Kehrer-Sawatzki H, Bartz U, Zoll B, Bohlander SK (2004) Molecular cytogenetic analysis of a de novo balanced $\mathrm{X}$; autosome translocation: evidence for predominant inactivation of the derivative $\mathrm{X}$ chromosome in a girl with multiple malformations. Am J Med Genet A 126A:229236. doi:10.1002/ajmg.a.20584

Hoshi O, Ushiki T (2011) Replication banding patterns in human chromosomes detected using 5-ethynyl-2'-deoxyuridine Incorporation. Acta Histochem Cytochem 44:233-237. doi:10.1267/ ahc. 11029

Keitges EA, Palmer CG (1986) Analysis of spreading of inactivation in eight $\mathrm{X}$ autosome translocations utilizing the high resolution RBG technique. Hum Genet 72:231-236

Latt SA (1973) Microfluorometric detection of deoxyribonucleic acid replication in human metaphase chromosomes. Proc Natl Acad Sci USA 70:3395-3399

Lee JT (2009) Lessons from X-chromosome inactivation: long ncRNA as guides and tethers to the epigenome. Genes Dev 23:1831-1842. doi:10.1101/gad.1811209

Lyon MF (1961) Gene action in the X-chromosome of the mouse (Mus musculus L.). Nature 190:372-373. doi:10.1038/190372a0

Mattei MG, Mattei JF, Ayme S, Giraud F (1982) X-autosome translocations: cytogenetic characteristics and their consequences. Hum Genet 61:295-309 
Mizuguchi T, Barrowman J, Grewal SS (2015) Chromosome domain architecture and dynamic organization of the fission yeast genome. FEBS Lett. doi:10.1016/j.febslet.2015.06.008

Moysés-Oliveira M, Guilherme RS, Dantas AG, Ueta R, Perez AB, Haidar M, Canonaco R, Meloni VA, Kosyakova N, Liehr T, Carvalheira GM, Melaragno MI (2015a) Genetic mechanisms leading to primary amenorrhea in balanced X-autosome translocations. Fertil Steril 103:1289-1296. doi:10.1016/j.fertnstert.2015.01.030

Moysés-Oliveira M, Guilherme RS, Meloni VA, Di Battista A, Mello CB, Bragagnolo S, Moretti-Ferreira D, Kosyakova N, Liehr T, Carvalheira GM, Melaragno MI (2015b) X-linked intellectual disability related genes disrupted by balanced X-autosome translocations. Am J Med Genet B Neuropsychiatr Genet. doi:10.1002/ajmg.b.32355

Panasiuk B, Usinskiené R, Kostyk E, Rybalko A, Stasiewicz-Jarocka B, Krzykwa B, Pienkowska-Grela B, Kucinskas V, Michalova K, Midro AT (2004) Genetic counselling in carriers of reciprocal chromosomal translocations involving short arm of chromosome X. Ann Genet 47:11-28. doi:10.1016/j.anngen.2004.01.001

Sakazume S, Ohashi H, Sasaki Y, Harada N, Nakanishi K, Sato H, Emi M, Endoh K, Sohma R, Kido Y, Toshiro N, Kubota T (2012) Spread of X-chromosome inactivation into chromosome 15 is associated with Prader-Willi syndrome phenotype in a boy with a t(X;15)(p21.1;q11.2) translocation. Hum Genet 131:121-130

Sato K, Uehara S, Hashiyada M, Nabeshima H, Sugawara J, Terada Y, Yaegashi N, Okamura K (2004) CpG dinucleotide methylation patterns in the human androgen receptor gene and X-chromosome inactivation in peripheral blood leukocytes of phenotypically normal women. J Hum Genet 48:374-379. doi:10.1002/ ajmg.a.30256

Schanz S, Steinbach P (1989) Investigation of the "variable spreading" of X inactivation into a translocated autosome. Hum Genet $82: 244-248$

Scheuerle A, Zenger-Hain JL, Dyke DLV, Ledbetter DH, Greenberg F, Shaffer LG (1995) Replication banding and molecular studies of a mosaic, unbalanced $\operatorname{dic}(\mathrm{X} ; 15)(X p t e r+X q 26.1: 15$ pll+15qter $)$. Am J Med Genet 56:403-408

Schluth C, Cossée M, Girard-Lemaire F, Carelle N, Dollfus H, Jeandidier E, Flori E (2007) Phenotype in X chromosome rearrangements: pitfalls of $X$ inactivation study. Pathol Biol 55:29-36. doi:10.1016/j.patbio.2006.04.003

Stankiewicz P, Kuechler A, Eller CD, Sahoo T, Baldermann C, Lieser U, Hesse M, Gläser C, Hagmann M, Yatsenko SA, Liehr T, Horsthemke B, Claussen U, Marahrens Y, Lupski JR, Hansmann I (2006) Minimal phenotype in a girl with trisomy $15 q$ due to $\mathrm{t}(\mathrm{X} ; 15)(\mathrm{q} 22.3 ; \mathrm{q} 11.2)$ translocation. Am J Med Genet A 140:442452. doi:10.1002/ajmg.a.31096

Stults DM, Killen MW, Pierce AJ (2014) The sister chromatid exchange (SCE) assay. Methods Mol Biol 1105:439-455. doi:10.1007/978-1-62703-739-6_32

Sumner AT (2003) Chromosomes: organization and function. Blackwell, Berlin

Tribioli C, Tamanini F, Patrosso C, Milanesi L, Villa A, Pergolizzi R, Maestrini E, Rivella S, Bione S, Mancini M, Vezzoni P, Toniolo D (1992) Methylation and sequence analysis around EagI sites: identification of 28 new CpG islands in XQ24-XQ28. Nucleic Acids Res 20:727-733

Willard HF, Latt SA (1976) Analysis of deoxyribonucleic acid replication in human $\mathrm{X}$ chromosomes by fluorescence microscopy. Am J Hum Genet 28:213-227

Yatsenko SA, Sahoo T, Rosenkranz M, Mendonza-Londono R, Naeem R, Scaglia F (2004) Attenuated phenotype in a child with trisomy for $1 \mathrm{q}$ due to unbalanced $\mathrm{X} ; 1$ translocation [46, $\mathrm{X}, \operatorname{der}(\mathrm{X}), \mathrm{t}(\mathrm{X} ; 1)(\mathrm{q} 28 ; \mathrm{q} 32.1)]$. Am J Med Genet A 128:72-77. doi:10.1002/ajmg.a.30094

Yeung KS, Chee YY, Luk HM, Kan ASY, Tnag MHY, Lau ET, Shuen AY, Lo IFM, Chan KYK, Chung BHY (2014) Spread of X inactivation on chromosome 15 is associated with a more severe phenotype in a girl with an unbalanced $\mathrm{t}(\mathrm{X} ; 15)$ translocation. Am J Med Genet A 164:2521-2528. doi:10.1002/ajmg.a.36670 